\title{
OPPORTUNITY ENTREPRENEURSHIP VS. NECESSITY ENTREPRENEURSHIP: IMMIGRANT ENTREPRENEURS IN THE EUROPEAN UNION
}

Antonio RICCI*

\begin{abstract}
There are more than 23 million SMEs in the EU-28, representing the vast majority of entrepreneurs, about two-thirds of all jobs and an even larger share of new employment positions. The potential impact of the sector is even greater, since the same documents produced by the Commission show that $38 \%$ of Europeans said they would prefer self-employment, whereas only one-tenth of the working age population is actually engaged in this sector.

Already at the beginning of 2016, there were more than 2 million self-employed immigrant workers. Moreover, according to the archives, this entrepreneurial reality is characterised by the following traits: a certain fragility; a reduced participation of women; the prevalence of low-skilled and less remunerative sectors of work; a young age of the workers; a prevalence of sole proprietorships / individual companies and, finally, a greater (or lesser) propensity to exercise an independent activity (depending on the areas of origin and/or settlement). At the same time, however, the data also show a strong capacity for renewal.

The present short essay starting from the distinction between the so called "opportunity entrepreneurship" and the "necessity entrepreneurship" (where selfemployment or entrepreneurship in traditional and less innovative sectors represents an alternative to unemployment caused by inadequate capital, nonrecognition of educational qualifications or language problems) intends to provide a general frame of the phenomenon of immigrant entrepreneurship in the EU and contribute in stressing the potential role that immigrants could play inside and outside the host communities, as well as all these factors limiting the potential of immigrant entrepreneurs and constituting further barriers they have to overcome in order to start their businesses.
\end{abstract}

Keywords: entrepreneurship, immigrant, european union, opportunity,necessity

\section{Introduction}

In recent years, studies carried out by $\operatorname{Eurostat}^{1}(2011), \mathrm{OECD}^{2}$ (2015) and other special programmes like the Migrant Integration Policy Index

\footnotetext{
* Reasercher PhD, IDOS Study and Research Centre, Via Arrigo Davila, 1600179, Roma, Italia (antonio.ricci@dossierimmigrazione.it).

1 European Commission, Indicators of immigrant integration 2011. A pilot study, Luxembourg, 2011.

${ }^{2}$ OECD, Indicators of immigrant integration 2015. Settling in, Paris, 2015.
} 
$\left(\right.$ Mipex $\left.^{3}\right)$, mainly based on Eurostat's statistical data, have tried to develop a considerable number of statistical indicators, emphasizing the link between integration and foreign entrepreneurship.

The role of self-employment as an index of integration, however, is still debated and the data presented in this contribution require more detailed analysis in order to take into account the specific situations of each Member States. Sometimes, in fact, self-employment may not be the true aspiration of an immigrant but only a temporary escape from a long unemployment period or from the discrimination within the labor market ${ }^{4}$.

Immigrant entrepreneurship is extremely interesting not only for the potential opportunities it offers to active integration in the host society. Moreover, as revealed by many scholars, immigrant entrepreneurship could significantly favour the creation of business networks - as well as transnational cooperation, thanks to investments - which involve both migrants' host and source countries.

The fundamental OECD report Open for Business migrant entrepreneurship in OECD countries, ${ }^{5}$, which since its first publication in 2010 has had the great merit of renewing studies on the relationship between immigrant entrepreneurship and the development of international trade, shows overwhelming evidence that "migrants increase trade between their present countries of residence and their countries of birth ${ }^{6}$. The

\footnotetext{
${ }^{3}$ http://www.mipex.eu/labour-market-mobility.

${ }^{4}$ European Commission, Indicators of immigrant integration 2011. A pilot study, Luxembourg, 2011, p. 70.

${ }^{5}$ OECD, Open for Business migrant entrepreneurship in OECD countries, Paris, 2010, p. 274.

${ }^{6}$ The OECD report also quotes several studies on the subject that should be mentioned (although in a synthetic and figurative way): "Gould (1994) found a statistically significant link between immigrants to the United States and US trade with their countries of origin. Head and Ries (1998) found a similar link for Canada, estimating an import elasticity at $0.3 \%$ and export elasticity at $0.1 \%$. Girma and Yu (2002) demonstrated a positive link between exports and immigration from countries outside the former British Empire, although no significant link could be demonstrated for migration within the former Empire. Further evidence of a positive migrant impact on trade was provided by Herander and Saavedra (2005), Bandyopadhyay et al. (2006), Dunlevy (2006) and Jansen e Piermartini (2009), as well as by Peri and Requena (2009)". See: Gould D.M. (1994), "Immigrant Links to the Home Country: Empirical Implications for US Bilateral Trade Flows", in "Review of Economics and Statistics", Vol. 76, No. 2, pp. 302-316; Head K. and Ries J. (1998), "Immigration and Trade Creation: Econometric Evidence from Canada", in “Canadian Journal of Economics", Vol. 31, No. 1, pp. 47-62; Girma S. and Yu Z. (2002), "The Link between Immigration and Trade: Evidence from the United Kingdom", in "Review of World Economics", Vol. 138, No. 1, pp. 1610-2878; Herander, M. and Saavedra L. (2005), "Exports and the Structure of Immigrant-Based Networks: The role of Geographic Proximity", in "Review of Economics and Statistics", Vol. 87, No. 2, pp. 323 335; Bandyopadhyay S., Coughlin C. and. Wall H. (2006), "Ethnic Networks and US Exports", Working Paper, Federal Reserve Bank of St. Louis; Dunlevy J. (2006), "The
} 
successive studies have found a significant and positive correlation between migration and trade ${ }^{7}$. However, the estimated positive impact varies considerably between $0.1 \%$ and $3.5 \%$ of increase in trade, as a result of an increase of $10 \%$ of the immigrant stock in a specific country.

\section{The global context}

In the last decades, as already occurred two centuries ago in the United States and Canada, immigrants proved to be a driving force for the European entrepreneurship. They started-up a growing number of businesses (at even higher rates than natives), gave rise to new sectors by stimulating demand and even went as far as to revitalize entire city neighborhoods (not just in the periphery), sometimes changing them into prosperous trade centers.

Even during the recent economic downturn in Europe, which was characterized by a succession of periods of economic expansion and contraction, immigrant entrepreneurs have continued to create new businesses and jobs - during both the favorable periods and the more problematic ones -, thus becoming a counter-balancing factor enabling stabilization.

The international survey agency Gallup ${ }^{8}$ estimated in 2013 that nearly one billion people - accounting for $29 \%$ of the total world's workforce - are entrepreneurs or self-employed. A really remarkable fact, if only it could be interpreted as the result of a strong proactive drive to start new economic activities. Unfortunately, as Gallup itself suggests, in reality this is not always the case, because in different areas of the world high self-

Influence of Corruption and Language on the Pro-Trade Effect of Immigrants: Evidence from the American States", in "Review of Economics and Statistics", Vol. 88, No. 1, pp. 182-186; Jansen M. and Piermartini R. (2009), "Temporary Migration and Bilateral Trade Flows", in "The World Economy", Vol. 32, No. 5, pp. 735-753; Peri G. and F. Requena (2009), "The Trade Creation Effect of Immigrants: Evidence from the Remarkable Case of Spain”, NBER Working Paper No. 15625, Cambridge.

${ }^{7}$ Moreover, continues the OECD report: "using OECD statistics, Lewer (2006) found that immigration stimulates bilateral trade between a cross-section of industrial countries and immigrant source countries. Felbermayr and Toubal (2008) and Lewer and Berg (2009) used a similar sample of countries, but expands the analysis to dismantle the channels through which migration may affect trade. Both confirm a positive impact of migrants on trade. Lewer and Berg conclude - inter alia - that migrants facilitate trade by creating and participating in networks that span across destination and native countries". See: Lewer J. (2006), "The impact of immigration on bilateral trade: OECD results from 1991-2000", in "Southwestern Economic Review", Vol. 33 (1), pp. 9-22; Lewer J. and Van den Berg H. (2009), "Does Immigration Stimulate International Trade? Measuring the Channels of Influence", in "International Trade Journal", Vol. 23, No. 2, pp. 187-230; Felbermayr J. and Toubal F. (2008), "Revisiting the Trade-Migration Nexus: Evidence from New OECD Data”, Working Paper, University of Stuttgart-Hohenheim and Paris School of Economics.

${ }^{8}$ http://www.gallup.com/poll/175292/nearly-three-workers-worldwide-self-employed.aspx. 
employment rates correspond to extremely difficult economic contexts, where self-employment is not a real opportunity for success or selffulfilment but rather a necessity to survive - sometimes even the only alternative to absolute poverty.

Globally, in fact, only the $18 \%$ of the self-employment workforce declares a flourishing economic condition and, in the areas of the world where it is most widespread such as South-East and East Asia or SubSaharan Africa, the remaining percentage lives in conditions of extreme poverty much more frequently than the rest of the population - being also characterized by a lower possibility of access to education (self-employed people living in those areas often stop at the level of primary education, and sometimes not even that).

On the contrary, in more developed areas such as North America or Europe, the incidence of entrepreneurs and self-employed on the total workforce decreases to 5-6\%, with educational levels which are higher than those of the overall population average, and profits comparable to those of an employed worker. However, this does not preclude that in some cases even in the most developed regions - people may find themselves forced to chose self-employment because they are unable to find a suitable job, or because of other adverse conditions.

Last but not least, the informal economy reaches a remarkable diffusion especially in less developed areas where, according to Gallup, only 3 people out of 10 declare the legal registration of their business - a precondition that hinders any aspiration to generate innovation and development and to evolve towards more structured entrepreneurial forms.

\section{The role of immigrants}

With all the necessary distinctions to correctly frame the phenomenon, the OECD Entrepreneurship at a Glance 2016 Report $^{9}$, having noted the positive connection between enterprise creation rate and production growth, suggested that - at that early stage of recovery from the economic crisis that began in 2008 - the recovery of entrepreneurialism could play a key role in providing an appreciable boost to productivity. Current trends generally appear to be growing and particularly positive in Canada, France, the Netherlands and the United Kingdom, where the enterprise creation rate is even higher than the pre-crisis level.

As also underlined by the Future of business survey ${ }^{10}$ (an online survey jointly promoted in 2016 by OECD, Facebook and the World Bank), in almost all countries it is precisely the most recently established SMEs

\footnotetext{
${ }^{9}$ OECD, Entrepreneurship at a Glance 2016 Report, Paris, 2016.

${ }^{10} \mathrm{https}$ ://blogs.worldbank.org/opendata/facebook-OECD-world-bank-have-new-waysurvey-businesses.
} 
(less than 3 years old) which have the best prospects for employment growth in the short term. On the contrary, the failure rate of entrepreneurial initiatives is: still significantly higher than in the pre-crisis phase in Austria, France and the Netherlands; more than double in Italy and even four times in Spain - with large margins of recovery, however, recorded during the last few quarters in the last two countries.

In the above-mentioned OECD report, it is also specified that SMEs can be an important driving force for post-crisis recovery, especially if traditional exports based on knowledge and niche activities are able to broaden their horizons beyond the markets of neighbouring countries, in order to penetrate successfully into emerging international markets, in which immigrants can increasingly play a bridging role.

In the recent World Economic and Social Outlook. Trends for Youth $2016^{11}$ the ILO highlights that the global youth unemployment rate is on the rise again, and is expected to reach $13.1 \%$ in 2016 - a significant increase compared to the $12.9 \%$ of the previous year. According to the International Labour Organization, the willingness to migrate in search of better job or training opportunities grows in presence of unemployment and/or vulnerable forms of employment (especially among youth in sub-Saharan Africa and Latin America). The Gallup world poll 2013-2016 ${ }^{12}$ provides a quantitative assessment of the phenomenon. According to this survey, globally there are as many as 710 million people willing to migrate (about $14 \%$ of all adults in the world).

Many of these people (almost following a selective model, i.e. accepting the risk of migration) seem to be theoretically more inclined to do business and seize the opportunity to start new enterprises, as well as to invest time and money to have access to additional sources of assistance, training and financing - thanks to the extraordinary ability to invest savings and extend social networks during their period of stay abroad. Reality, then, is not very far from theory. On the one hand, the OECD's 2011 International Migration Outlook had already highlighted that, in the majority of developed countries, the highest rates of self-employment were found among immigrants rather than the rest of the population ${ }^{13}$. On the other hand, as recorded by the Global Entrepreneurship Monitor in 2012, within each of the 69 countries monitored, the creation rate of start-ups among immigrants and locals are quite similar, as are their characteristics in the various countries - especially in terms of innovation ${ }^{14}$.

\footnotetext{
${ }^{11}$ ILO, World Economic and Social Outlook. Trends for Youth 2016, Geneva, 2016.

${ }^{12}$ Gallup, World poll 2013-2016, Washington, 2017.

${ }^{13}$ OECD, International migration outlook del 2011, Paris 2011, pp. 139-203.

${ }^{14}$ GEM, Global entrepreneurship monitor, London, 2012, pp. 42-50.
} 
In everyday life, the wide range of discrimination to which immigrants can be subjected and the conditions of greater vulnerability are the factors that most hinder immigrants' entrepreneurship, limiting their prospects of success (if not their very subsistence). However, there are also examples of good practices such as the United States, where the implementation of policies aimed at attracting skilled labour force from abroad and/or training it on the ground, combined with high level of integration, has in fact expanded the potential for entrepreneurship, producing a significant number of successful immigrant entrepreneurs. Perfect examples are the companies working in the Silicon Valley, the famous American high technology district where 50\% of the enterprises have been founded by immigrant graduates from American colleges.

What we could define as "opportunity entrepreneurship" stands in contrast to the "necessity entrepreneurship", where self-employment or entrepreneurship in traditional and less innovative sectors represents an alternative to unemployment caused by inadequate capital, non-recognition of educational qualifications or language problems ${ }^{15}$.

\section{The European Union context}

In the EU, even though entry procedures and possible incentive policies are not harmonised, the idea of promoting immigrant entrepreneurship as a medium to long term development is now well established, as also underlined in the Action Plan Entrepreneurship 2020 $\left(\mathrm{COM}(2012) 795\right.$ final). The same public consultation ${ }^{16}$ that preceded the Action Plan highlighted how the heterogeneity of the current legislation is actually a barrier limiting migration flows, whereas it would be necessary to offer them specific support measures. On the one hand, these measures would allow the empowerment of entrepreneurial skills through the strengthening of immigrants' human capital (thus improving their ability to do business); on the other hand, they would aim at removing structural barriers, improving market conditions, implementing favourable regulations, strengthening intermediary organisations and, last but not least, facilitating access to credit in a climate of genuine equal opportunities.

The same 2011 European Agenda for the Integration of ThirdCountry Nationals (COM(2011) 455 final e SEC(2011) 957 final) has also dealt with these lines of actions, underlining that the entrepreneurial role and creativity of immigrants must be enhanced. At both European and national level, the Agenda highlighted that on the one hand immigrant entrepreneurs

\footnotetext{
${ }^{15}$ OECD-Eurostat Entrepreneurship Indicators Programme, A Collection of indicators. 2009 edition, Paris, 2009.

${ }^{16} \mathrm{http}$ ://ec.europa.eu/enterprise/policies/sme/files/entrepreneurship-2020/final-report-pubcons-entr2020-ap_en.pdf.
} 
contribute to the economic growth of a country (although often working in marginal sectors) and on the other hand that the situation is not yet satisfactory despite the fact that there have been many initiatives to attract, encourage and support this entrepreneurial reality. "At the moment, ethnic entrepreneurship is not an important part of the European integration policy for migrants. Entrepreneurship is not only about the job creation, but also about enhancing upward mobility, developing social leadership, increasing individuals' self-confidence by enabling them to become active agents of their own destiny, increasing the social cohesion of ethnic communities, and revitalising streets and neighbourhoods through innovation of social and cultural life", ${ }^{\prime 17}$.

While awaiting a forthcoming harmonisation of the regulations and therefore of the data collected through the national business registers currently operating in each Member State (in Italy this role is played by Infocamere), the only comparable statistical source - despite its limitations is the EU-LFS (Labour Force Survey), a quarterly EU-wide sample statistical survey which provides estimates of the main characteristics of the labour market - with reference to the resident population over 15 years of age. According to the EU-LFS, "self employed persons" include selfemployed workers, entrepreneurs and all those people who work in their own business, farm or professional practice, who meet one of the following criteria: working for the purpose of earning profit, spending time on the operation of a business or being in the process of setting up his/her business in the immediate future.

Due to its nature of survey and the obvious quantitative limitations in terms of sampling, the EU-LFS loses its effectiveness as it approaches a micro-level (as in the case of self-employed workers analysed within the labour market), thus limiting the elaboration of more precise disaggregations. Furthermore, the data concerning holders of residence permits for self-employment is not yet available, since the latter are generally aggregated by Eurostat in the broadest category of holders of a residence permit for "remunerated activities".

According to the EU-LFS, in 2016 self employed workers aged between 15 and 74 residing in the EU-28 are 32,716,000, 2,180,400 of whom are foreigners ${ }^{18}(1,042,000$ non-EU and 1,138,400 EU citizens), with an incidence on the total of $6.7 \%$ (about 1 out of 15). Within the single Member States, this figure ranges from $50.0 \%$ in Luxembourg to $0.4 \%$ in Poland, with Italy falling slightly below the EU average (at $6.0 \%$ ), thus

\footnotetext{
${ }^{17}$ Rath J., Swagerman A., Promoting ethnic entrepreneurship in European cities, Publications Office of the EU, Luxembourg, 2011, www.coe.int/t/democracy/migration/Source/migration/congress_public_3.pdf.

${ }^{18}$ The aggregate figure does not include the breakdowns for Bulgaria, Croatia, Lithuania and Romania, which are not available in the Eurostat archives.
} 
confirming the large growth margins that could characterise its immediate future.

In the first decade of the 2000s, immigrant entrepreneurship had already shown a favourable trend, as documented by the "European Employment Observatory" in the Self-employment in Europe 2010 document (Brussels, 2010). The growth of the services sector supported this increase, particularly thanks to the application of technological innovations in the telecommunications sector. Our elaborations on data referring to the period 2006-2016 show that, compared to the total number of self-employed workers (which remained practically the same), the number of selfemployed workers with foreign citizenship grew from 1,366,500 in 2006 to $2,180,400$ in 2016, with an increase of almost $60 \%$ : this despite the fact that the growth rate had virtually stopped between 2008 and 2010 (the worse phase of the economic downturn), when many self-employed people run the risk of falling below the poverty line. As regards individual Member States, the most significant increases in absolute terms were recorded in the United Kingdom $(+293,700)$, Italy $(+122,400)$ and Germany $(+104,600)$, whereas in relative terms in Denmark $(+136.0 \%)$, the United Kingdom $(122.2 \%)$ and Luxembourg (122.1\%).

The incidence of non-EU self-employed workers varies greatly between Member States:

- a first group is that of the so-called "border Member States", characterized by important minorities with a presence of more than 90\% (Latvia 96.8\%, Estonia 94.4\%, Slovenia 90.3\%), or by a particular geographic position like the Mediterranean countries (Greece $77.9 \%$ and Italy 73.2\%) or Central Europe (Czech Republic 75.9\%, Hungary $67.3 \%$ and Poland $66.4 \%$ );

- a second group mainly consists of "central Member States", which due to their specific geographical location and geopolitical condition within the EU - particularly benefit of the intra-EU mobility (Luxembourg 5.0\%, Belgium 19.8\%, Ireland 24.1\%, Austria 33.5\%, Sweden 34.6\%, United Kingdom 35.4\%);

- a third and last group is made up of countries that deviate from the average $(47.8 \%)$ by 5 percentage points more (France $54.6 \%$, Spain $53.7 \%$ and Malta $50.0 \%$ ) or less (Germany $42.2 \%$ ).

Italy, with 5,069,800 Italian and foreign entrepreneurs, represents:

- the first European country in terms of entrepreneurial initiative, representing one-sixth of the total number of self-employed workers operating in the EU-28;

- the third country by number of foreign self-employed workers, $80 \%$ of whom (in 2016) concentrated in only 5 Member States: 534,200 
in the United Kingdom, 462,600 in Germany, 305,900 in Italy ${ }^{19}$, 284,300 in Spain and 199,300 in France;

- the first country in the EU-28 for the number of self-employed nonEU workers $(223,900)$ and the fourth for EU workers $(82,000)$.

\section{In-depth analysis of EU-LFS data}

In the EU-28 the rate of self-employment, i.e. the incidence of selfemployed workers on total employment, is $12.8 \%$ among foreigners and $14.6 \%$ among the total population. Among foreigners, the highest numbers can be found among the former Communist countries, such as Slovakia (31.4\%), Poland (26.0\%), Czech Republic (21.4\%) and Hungary (17.4\%). As confirmed by the high incidence of non-EU nationals, these are mainly citizens from Vietnam, Syria and Turkey, who have started small businesses in the retail and catering sectors since the early $1990 \mathrm{~s}^{20}$.

The analytical picture changes little if, in place of foreign citizens, one considers those born abroad: the rate of self-employment is $14.4 \%$ for locals, $14.0 \%$ for immigrants born in another Member State and 13.9\% for immigrants born outside the EU-28.

Female participation is also a minority both in general $(32.3 \%)$ and among foreign citizens (32.0\%), with peaks above 50\% among foreign selfemployed workers in Portugal (54.6\%) and Denmark (50.8\%). As far as age groups are concerned, the significant contribution of immigrants to the rejuvenation of the self-employed must be underlined. While the age group between 25 and 49 accounts for $71.9 \%$ among the former, in fact, it falls to $55.2 \%$ among the latter. Those residing in Italy (79.9\%) and the United Kingdom $(76.8 \%)$ represent the largest number of foreign self-employed workers in the 25-49 age group. Obviously, the longer the stay is, the greater the chances of starting a self-employed activity can be - which goes along with new opportunities and better insertion paths. Together with age, the desire to earn more and escape from situations of discrimination - as often happens with low-skilled and low paid jobs - may also represent an important motivation for women.

The EU-LFS further distinguishes between "own-account workers" and "employers", a distinction which - although not exactly corresponding to the distinction between self-employed workers and entrepreneurs tout court - seems to suggest a first differentiation between the two categories. In

\footnotetext{
${ }^{19}$ The data is significantly underestimated compared to the archives of the national register managed by Infocamere, even if the latter is not based on the nationality of the selfemployed worker/entrepreneur but on the number of enterprises run by persons born abroad registered in the provincial Chambers of Commerce.

${ }^{20}$ Settlement, in some cases, dates back to the years of real socialism when students from other communist countries were received through solidarity programs. See: Forti O., Pittau F., Ricci A., Europa. Allargamento a Est e immigrazione, Idos, Rome, 2004.
} 
2016, foreign self-employed workers who employ other people account for a few percentage points less than the total number of self-employed workers: $25.2 \%$ vs $28.1 \%$, or 550,000 vs. 9.2 million.

If we take into account only the top 5 countries for number of foreign self-employed workers (that is $80 \%$ of the total, as previously mentioned), Germany $36.9 \%$ (44.3\%) and France $30.0 \%$ (37.3\%) are above the average, Spain $26.7 \%(30.1 \%)$ is around the average, whereas Italy $19.5 \%(28.6 \%)$ and the United Kingdom $13.2 \%(16.1 \%)$ are below average. Each of these countries, however, presents a significant unfavourable deviation from the values in brackets, which refer to the total number of self-employed workers. Only in six Member states, in fact, the incidence of employers on the total of foreign self-employed workers is higher than the corresponding figure for national and foreign self-employed workers together: Czech Republic, Denmark, Estonia, Hungary, Latvia, Slovenia and Estonia.

Although there are no specific data available, in some Member States the field surveys show that immigrant entrepreneurship tends to concentrate on less innovative, low value-added and more price competitive sectors. All these factors limit the potential of immigrant entrepreneurs and constitute further barriers they have to overcome in order to start their businesses. Nevertheless, we should not generalise but rather carry out analyses that go beyond stereotypes and take into account the heterogeneity of the large group of foreign self-employed workers and entrepreneurs - since (as shown by the data in our possession) these people are anyway able to fulfil their potential while developing themselves and employing a considerable number of people ${ }^{21}$.

\section{Conclusions}

Despite the fact that in recent years international and intergovernmental bodies (such as the OECD and the European Commission) have increasingly committed themselves to study and manage this phenomenon, the scientific literature is not yet able to isolate the incontrovertible causality relationships regarding the link with economic development processes.

The above-mentioned studies and data confirm the need for further investigation and deepening in order to understand the multifaceted complexity of immigrant entrepreneurship and its strategic importance in terms of development and integration, as well as the urgency of overcoming chronic governance failures.

In this sense, the European Union seems to be a formidable laboratory as regards the possibility of observing the direct impact on both the

\footnotetext{
${ }^{21}$ OECD, The missing entrepreneurs 2015 Policies for self-employment and entrepreneurship, Paris, 2015.
} 
countries of settlement and (indirectly) the countries of origin - in the latter case by means of remittances sent by temporary migrants or beneficiaries of assisted voluntary return projects in anticipation of their return ${ }^{22}$.

However, the EU-LFS and the other national surveys - whose data are mainly based on estimates - are unable to collect and provide sufficient information on several key aspects such as the business sectors, countries and areas of origin, the duration of entrepreneurial initiatives, their profit and salaries paid to employees, their real effectiveness in creating new jobs, their impact on the economy in general, the level of education and social capital of entrepreneurs, and so on.

Therefore, starting from the available information and taking into account the above-mentioned statistical gaps, the conclusion of this contribution is that, today, joining efforts in order to create a "European Observatory" seems more urgent than ever. This Observatory, by promoting specific surveys and making full use of the unlimited knowledge potential offered by the various national registers, should: i) develop specific assistance programmes; ii) monitor and evaluate current policies; iii) propose policy recommendations tailored to real needs, not just to mere perceptions or stereotypes. A pilot attempt to develop such a kind of tool could be considered the annual report edited by IDOS and dedicated to Immigration and Entrepreneurship in Italythat in 2020 will reach the fifth edition.The Report on Immigration and Entrepreneurship, by analysing the Italian case within the European framework, could be considered a synthesis of all the various dimensions of the phenomenon and "shows how the institutional and social world must proceed together in recognizing and enhancing the contribution of immigrant citizens to the national and European business system. The awareness that the development of the enterprise fabric in our country (and therefore of its wellbeing) also depends on the consolidation of the contribution of immigrant enterprises is essential",23.

\footnotetext{
${ }^{22}$ OECD, Perspectives on global development 2017: International migration in a shifting world, Paris, 2016.

${ }^{23}$ Vaccarino D., Canovi M., Melchionda Ugo, L'imprenditoria degli immigrati: una questione a dimensione europea. Introduzione alla Quarta edizione del Rapporto Immigrazione e Imprenditoria/Immigrant Entrepreneurship: a European issue Introduction to the Fourth Edition of the Report on Immigration and Entrepreneurship, in Centro Studi e Ricerche IDOS, Rapporto Immigrazione e Imprenditoria 2017/ Report on Immigration and Entrepreneurship 2017 (bilingual edition), IDOS, Rome, 2018, p. 10/10.
} 
EUROPEAN UNION. Total self-employed and foreign workers (EU and non-EU) aged between 15 and 74 years by country of residence. Numbers in thousands (a.v.) and percentages (2016)

\begin{tabular}{|c|c|c|c|c|c|c|c|c|c|c|c|c|c|c|c|c|}
\hline & TOTALS & ITALIAN & AND FORE & IGNERS) & & FOREI & GNERS & & & EU- & $28 *$ & & & NON. & $-\mathrm{UE}$ & \\
\hline Country & $\begin{array}{l}\text { Self- } \\
\text { employ } \\
\text { ed } \\
\text { (a.v.) }\end{array}$ & $\begin{array}{c}\text { Female } \\
s(\%)\end{array}$ & $\begin{array}{c}\text { With } \\
\text { employe } \\
\text { es }(\%)\end{array}$ & $\begin{array}{l}\% \text { of } \\
\text { self- } \\
\text { employ } \\
\text { ed on } \\
\text { total } \\
\text { employ } \\
\text { ed }(\%) \\
\end{array}$ & $\begin{array}{c}\text { Self- } \\
\text { employ } \\
\text { ed } \\
\text { (a.v.) }\end{array}$ & $\begin{array}{c}\text { Female } \\
s(\%)\end{array}$ & $\begin{array}{c}\text { With } \\
\text { employe } \\
\text { es }(\%)\end{array}$ & $\begin{array}{c}\% \text { of } \\
\text { self- } \\
\text { employ } \\
\text { ed on } \\
\text { total } \\
\text { employ } \\
\text { ed }(\%)\end{array}$ & $\begin{array}{l}\text { Self- } \\
\text { employ } \\
\text { ed } \\
\text { (a.v.) }\end{array}$ & $\begin{array}{c}\text { Female } \\
s(\%)\end{array}$ & $\begin{array}{c}\text { With } \\
\text { employe } \\
\text { es }(\%)\end{array}$ & $\begin{array}{c}\% \text { of } \\
\text { self- } \\
\text { employ } \\
\text { ed on } \\
\text { total } \\
\text { employ } \\
\text { ed }(\%) \\
\end{array}$ & $\begin{array}{c}\text { Self- } \\
\text { employ } \\
\text { ed } \\
\text { (a.v.) }\end{array}$ & $\begin{array}{c}\text { Female } \\
s(\%)\end{array}$ & $\begin{array}{c}\text { With } \\
\text { employe } \\
\text { es }(\%)\end{array}$ & $\begin{array}{c}\% \text { of } \\
\text { self- } \\
\text { employe } \\
\text { d on } \\
\text { total } \\
\text { employe } \\
d(\%)\end{array}$ \\
\hline Belgium & 638.7 & 31.2 & 29.8 & 14.0 & 76.8 & 25.9 & 24.7 & 16.2 & 61.7 & 26.3 & 23.5 & 17.7 & 15.2 & 24.3 & 28.9 & 12.1 \\
\hline Bulgaria & 334.4 & 34.0 & 32.0 & 11.1 & - & - & - & - & - & - & - & - & - & - & - & - \\
\hline $\begin{array}{l}\text { Czech } \\
\text { Rep. }\end{array}$ & 849.6 & 32.5 & 18.9 & 16.6 & 22.4 & 27.7 & 28.6 & 21.4 & 5.5 & 20.0 & 23.6 & 9.9 & 17.0 & 30.0 & 30.0 & 34.5 \\
\hline Denmark & 235.3 & 28.8 & 41.3 & 8.3 & 17.7 & 44.1 & 41.8 & 7.3 & 8.9 & 39.3 & 43.8 & 7.4 & 8.8 & \begin{tabular}{l|l}
47.7 \\
\end{tabular} & 39.8 & 7.2 \\
\hline Germany & $4,073.4$ & 33.1 & 44.3 & 9.9 & 462.6 & 28.9 & 36.9 & 10.5 & 267.4 & 27.6 & 35.0 & 11.2 & 195.2 & \begin{tabular}{|l|}
30.7 \\
\end{tabular} & 39.5 & 9.6 \\
\hline Estonia & 60.4 & 34.3 & 41.4 & 9.4 & 7.2 & 33.3 & 48.6 & 8.1 & - & - & - & - & 6.8 & 35.3 & 50.0 & 8.0 \\
\hline Ireland & 317.7 & 21.3 & 29.2 & 15.8 & 30.3 & 32.3 & 20.8 & 9.7 & 23.0 & 30.9 & 17.8 & 10.7 & 7.3 & 35.6 & 30.1 & 7.4 \\
\hline Greeece & $1,105.3$ & 33.0 & 24.5 & 30.1 & 23.1 & 25.5 & 15.2 & 10.2 & 5.1 & 39.2 & - & 12.7 & 18.0 & 21.7 & 14.4 & 9.6 \\
\hline Spain & $3,012.1$ & 33.5 & 30.1 & 16.4 & 284.3 & 37.4 & 26.7 & 14.4 & 131.5 & 37.2 & 29.0 & 16.9 & 152.8 & \begin{tabular}{|l|l|}
37.6 \\
\end{tabular} & 24.7 & 12.7 \\
\hline France & $3,019.2$ & 32.9 & 37.3 & 11.4 & 199.3 & 25.9 & 30.0 & 13.5 & 90.5 & 33.3 & 25.4 & 14.7 & 108.8 & 19.9 & 33.6 & 12.6 \\
\hline Croatia & 196.5 & 31.2 & 41.9 & 12.4 & & - & - & - & - & & - & & - & - & - & \\
\hline Italy & $5,069.8$ & 30.5 & 28.6 & 22.4 & 305.9 & 28.8 & 19.5 & 12.7 & 82.0 & 41.3 & 18.4 & 10.3 & 223.9 & 24.1 & 19.9 & 14.0 \\
\hline Cyprus & 46.5 & 33.8 & 13.8 & 12.7 & 6.3 & 50.8 & - & 8.8 & 4.0 & 52.5 & - & 8.9 & 2.3 & 47.8 & - & 8.8 \\
\hline Latvia & 107.5 & 39.1 & 35.2 & 12.0 & 12.5 & 40.8 & 45.6 & 11.3 & - & - & - & - & 12.1 & 39.7 & 46.3 & 11.1 \\
\hline Lithuania & 153.1 & 37.7 & 21.0 & 11.3 & & - & - & - & - & - & - & - & - & - & - & - \\
\hline $\begin{array}{l}\text { Luxembou } \\
\text { rg }\end{array}$ & 24.0 & 37.1 & 42.5 & 9.2 & 12.0 & 39.2 & 36.7 & 8.9 & 11.3 & 39.8 & 37.2 & 9.1 & 0.6 & - & - & 5.6 \\
\hline Hungary & 454.2 & 34.1 & 47.3 & 10.4 & 4.9 & - & 85.7 & 17.4 & & - & - & - & 3.3 & - & 90.9 & 27.7 \\
\hline Malta & 25.8 & 17.4 & 34.1 & 13.5 & 1.4 & 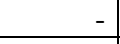 & 28.6 & 19.7 & 0.7 & - & - & 24.1 & 0.7 & - & - & 16.7 \\
\hline Netherland & $1,366.1$ & 35.6 & 24.7 & 16.3 & 55.6 & 38.1 & 18.3 & 16.3 & 33.2 & 38.6 & 15.7 & 16.7 & 22.4 & 37.5 & 21.9 & 15.7 \\
\hline
\end{tabular}


BULETIN STIINT⿱FIC, FASCICULA FILOLOGIE, SERIA A, VOL. XXVIII, 2019

\begin{tabular}{|c|c|c|c|c|c|c|c|c|c|c|c|c|c|c|c|c|}
\hline $\mathrm{s}$ & & & & & & & & & & & & & & & & \\
\hline Austria & 468.4 & 35.4 & 40.8 & 11.1 & 50.7 & 42.4 & 34.7 & 8.3 & 33.7 & 44.2 & 24.6 & 9.6 & 17.0 & 39.4 & 54.7 & 6.6 \\
\hline Poland & $2,909.2$ & 32.3 & 21.9 & 18.0 & 12.2 & - & - & 26.0 & - & - & - & - & 8.1 & - & - & 22.8 \\
\hline Portugal & 732.1 & 36.6 & 29.5 & 16.1 & 16.3 & 54.6 & - & 15.4 & 4.9 & - & - & 20.8 & 11.4 & 55.3 & - & 13.9 \\
\hline Romania & $1,531.6$ & 27.8 & 5.7 & 18.1 & - & - & - & - & - & - & - & - & - & - & - & - \\
\hline Slovenia & 107.4 & 29.9 & 31.2 & 11.8 & 3.1 & - & 32.3 & 8.1 & - & - & - & - & 2.8 & - & 35.7 & 8.3 \\
\hline Slovakia & 381.5 & 30.6 & 20.9 & 15.3 & 2.2 & - & - & 31.4 & - & - & - & - & - & - & - & - \\
\hline Finland & 330.7 & 31.8 & 30.0 & 13.5 & 9.4 & 40.4 & 24.5 & 12.5 & 4.4 & - & - & 10.9 & 5.0 & 42.0 & - & 14.3 \\
\hline Sweden & 477.9 & 28.7 & 37.4 & 9.7 & 25.7 & 37.0 & 33.5 & 8.9 & 16.7 & 34.1 & 32.3 & 12.3 & 8.9 & 42.7 & 36.0 & 5.8 \\
\hline $\begin{array}{l}\text { United } \\
\text { King. }\end{array}$ & $4,687.6$ & 32.6 & 16.1 & 14.9 & 534.2 & 34.1 & 13.2 & 15.6 & 344.7 & 35.2 & 9.5 & 15.5 & 189.6 & 31.9 & 19.9 & 15.6 \\
\hline EU-28 & $\begin{array}{r}32,716 . \\
0\end{array}$ & 32.3 & 28.2 & 14.6 & $2,180.4$ & 32.0 & 25.1 & 12.8 & $1,138.4$ & 33.8 & 22.6 & 13.3 & $1,042.0$ & 30.1 & 27.9 & 12.3 \\
\hline
\end{tabular}

SOURCE: Study and Research Centre IDOS.Calculations on Eurostat/EU - Labour Force Survey data 